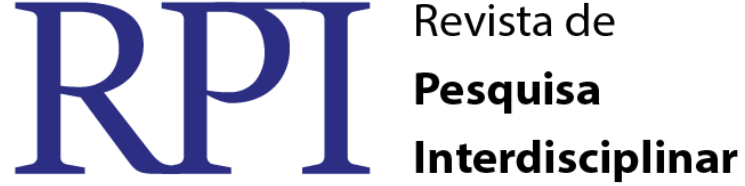

\section{A RELAÇÃO PROFESSOR-ALUNO E A QUESTÃO DA ÉTICA}

\author{
Daniela Ferreira de Freitas-UFCG \\ Francisca Daiana Estrela Silva-UFCG
}

\begin{abstract}
RESUMO
Este artigo visa uma reflexão sobre a relação professor-aluno no campo da ética, do qual a partir de alguns exemplos práticos do cotidiano, questionamentos surgem sobre o que é ser ético, como ser ético e o papel do professor nessa problemática. Nesta lógica de pensamento o artigo apresenta como objetivo refletir a ética da e na educação no tempo presente na relação professor-aluno no âmbito da sala de aula, sendo que na perspectiva dessa relação do educador com o educando, se faz necessário um discurso pautado na participação prática do professor partindo dos seus próprios exemplos. Assim sendo, o texto pretende contribuir na discussão e compreensão sobre a ética que se constitui na sala de aula e esclarecer alguns conceitos, como ética e moral, pois é relevante entender a diferença entre a ética e o discurso ético e o espaço do educador e do educando nessa problemática que se faz presente em nossa sociedade, sendo a ética apresentada como uma reflexão crítica sobre a moralidade. Para que isso ocorra de forma satisfatória, o trabalho foi desenvolvido mediante a utilização de pesquisa bibliográfica, por meio de uma abordagem qualitativa. Conclusão e resultados obtidos mostram que não existe educação sem ética, sendo essas interligadas e essenciais na formação do aluno. Também é relevante ressaltar que há uma interação entre ética-escola-sociedade, onde o aluno tende a repercutir em sociedade o que vivencia na escola. Por ser um tema bastante abrangente e complexo, aprimorar os conhecimentos sobre ética é necessário por todos os profissionais, principalmente aos docentes que trabalham diretamente na formação dos cidadãos.
\end{abstract}

Palavras - chave: Ética, Cotidiano, Professor-aluno.

\begin{abstract}
:
This article aims to reflect on the teacher-student relationship in the field of ethics, which from some practical examples of everyday life, questions arise about what is ethical, how to be ethical and the teacher's role in this issue. In this logic thought the article has as objective to reflect the ethics and education at the present time the teacher-student relationship in the classroom, and in view of this the educator relationship with the student, a guided speech is necessary in practical participation of the teacher leaving their own examples. Therefore, the text aims to contribute to the discussion and understanding of ethics that is in the classroom and to clarify concepts such as ethics and morality, it is important to understand the difference between ethics and ethical discourse and the space educator and the student in this issue that is present in our society, and ethics presented as a critical reflection on morality. For this to occur satisfactorily, the work was developed through the use of literature, through a qualitative approach. Conclusion and results show that there is no education without ethics, and these interconnected and essential in the formation of the student. It is also important to point out that there is an interaction between ethics-school-society, where the student tends to reverberate in society that experiences at school. Being a very broad and complex subject, improve the knowledge of ethics is necessary for all professionals, especially for teachers who work directly in the formation of citizens.
\end{abstract}

Keywords: Ethics, Daily Life, teacher -student. 


\section{INTRODUÇÃO}

Este artigo visa uma reflexão sobre a ética da e na educação no tempo presente. Para fundamentá-lo nos referenciamos nos pensamentos de RIOS (2011), LIBÂNEO (2008), CORTELLA (2012), FREIRE (2011), LIPMAN (1990), entre outros, além das discussões, leituras e debates em sala de aula, realizada na disciplina Ética e educação, ministrada no curso de licenciatura em Pedagogia, na Universidade Federal de Campina Grande, campus de cajazeiras.

Considerando a ética como ato de reflexão, nada mais justo do que aplicá-la à relação professor-aluno, já que essa deve estar munida de atos reflexivos e, portanto, éticos. Não é novidade a relevância dessa relação para o processo de ensino-aprendizagem, pois é através dela que os conhecimentos são apreendidos, e será em torno dessa temática que irei conduzir minhas reflexões, indagações e contribuições neste artigo.

Também se faz presente em tal artigo, questões variadas, mas relevantes em torno da ética na relação professor-aluno, essas serão desenvolvidas para a melhor compreensão do processo ensino-aprendizagem, tais como a diferença entre a teoria e sua prática, o modismo do discurso ético e as dificuldades sociais, a equidade e respeito, a posição que o aluno ocupa na questão ética, sempre presentes na educação brasileira.

Considerando essas questões, o objetivo desse artigo é refletir sobre a relaçãoprofessor aluno relacionando-a com a ética. Nesse sentido a questão que norteia este trabalho é: Como a ética está sendo desenvolvida na relação professor-aluno dentro da sala de aula?

\section{A ética segundo a perspectiva da relação professor aluno.}

Sabemos que a educação está impregnada de ética, pois toda instituição e todos os indivíduos carregam na vida suas regras e valores. Porém é interessante analisar como esse tema está sendo tratado dentro da sala de aula, se está realmente sendo cumprida a função nuclear da ética que segundo Rios, (2011, p.94) "É o respeito-dele decorrem os outros. Respeitar implica, em primeiro lugar, reconhecer a presença do outro como igual, em sua humanidade”. Esse sentido de equidade e respeito deve ser norteador dessa relação. 
Para compreendermos esse processo e sua importância é necessário primeiramente esclarecer alguns conceitos, iniciando pela ética. Segundo Rios (2011, p.34) “A ética se apresenta como uma reflexão crítica sobre a moralidade, sobre a dimensão moral do comportamento do homem." Sendo assim, não se trata de qualquer reflexão, mas sim de uma reflexão crítica, sobre a moral, os costumes dos homens e a escola, necessariamente o professor com sua capacidade de trabalhar pela transformação social, lidando diretamente com os educandos, pode intervir para que essa ação reflexiva ocorra. Também é interessante destacar que para Vásquez (Apud RIOS, 2011, p.), a moral é considerada como "Um conjunto de normas e regras destinadas a regular as relações dos indivíduos em uma comunidade social dada.” Isto é, as regras que são impostas por determinadas sociedades.

Nos sentidos de ética e moral acima elencados, podemos compreender que a relação professor-aluno seja envolvida pela questão da ética. Neste caso, segundo Libâneo (2008, p.249), podemos conceituar a relação professor-aluno como sendo "um aspecto fundamental da organização da 'situação didática', tendo em vista alcançar os objetivos do processo de ensino: a transmissão e assimilação dos conhecimentos, hábitos e habilidades.”. Sendo que a ética, junto com a moral, estão inseridas dentro desses hábitos.

Depois de esclarecido esses conceitos, entraremos em uma discussão que se faz presente cotidianamente que é a diferença entre a ética que se proclama e a prática da mesma, que em muitas situações se diferem. Isso ocorre por estarmos vivenciando um momento em que a ética está na moda, ou melhor, o discurso ético, não sendo interessante contrariar esse discurso, fazendo com que os indivíduos utilizem desse para disfarçar seus atos não- éticos. Segundo Cortella (2012, p108) "Algo contrário a uma ética compartilhada e aceita", O professor em sala de aula fala da importância da fila para a organização, e o quanto é antiético "corta a fila", mas quando tem oportunidade de passar à frente de um idoso em uma fila, o faz. Desta forma, há um descontrole, um distanciamento entre o discurso e a ação. Sobre essa questão Rios (2011, p.85) expressa a seguinte questão:

É preciso, entretanto, estarmos atentos para o fato de que, muitas vezes, o apelo à ética se faz apenas no discurso e está ausente na pratica das relações cotidianas. Daí a necessidade de fazermos constantemente o exercício da reflexão crítica, característica da filosofia, para identificar os limites e explorar as possibilidades de uma efetiva presença da ética.

Por que é tão difícil ser ético em nossa sociedade? E Qual o papel do professor nessa problemática? A sociedade brasileira acostumou-se a levar vantagem sobre o outro, como reza RPIRevista de Pesquisa Interdisciplinar, Cajazeiras, v. 1, Ed. Especial, 92 - 98, set/dez. de 2016. 
o senso crítico o chamado "jeitinho brasileiro", o que não condiz com a ética, tornando socialmente o individuo que a segue como um tolo. Atitudes essas que refletem dentro da sala de aula, quando o aluno deixa de estudar para colar, quando o professor pega atestado falso para não trabalhar, entre outras coisas.

É necessário que a relação professor-aluno seja pautada pela honestidade e trate a ética como uma prática, não como um discurso vazio. O interessante é que o professor eduque pautado na ética e a utilize no processo de formação como uma fonte de inspiração para reflexões críticas de suas atuais e futuras ações, nesse processo o educando assimila e reproduz o que apreende na sala de aula para a sociedade, pois o professor não está proporcionando aprendizagem só com suas palavras, mas também com suas atitudes e com seus gestos. Nesse sentido é importante o que afirma Freire (2011, p.34). Quando diz que:

O professor que realmente ensina, quer dizer, que trabalha os conteúdos no quadro da rigorosidade do pensar certo, nega, como falsa, a fórmula farisaica do "faça o que eu mando e não faça o que eu faço". Quem pensar certo está cansado de saber que as palavras a que falta a corporeidade do exemplo pouco ou quase nada valem. Pensar certo é fazer certo.

\section{Ética e competência em sala de aula.}

Dentro de todas as relações se faz necessário o respeito e a igualdade entre os sujeitos, princípios esses éticos, incluindo-se assim a relação professor-aluno, porém será que esses princípios estão realmente sendo cumpridos? Quando o professor traz para sua sala de aula metodologias e discursos autoritaristas, conceitos e valores prontos, está desrespeitando o educando, retirando dele a liberdade de seus pensamentos reflexivos. Afinal os valores e as reflexões mudam de indivíduo para indivíduo, não havendo espaço para teorias acabadas. Nesse sentido Lipman (1990, p.67) discorre que:

O objetivo não é dar às crianças teorias éticas acabadas pelas quais devam se conduzir, mas sim, equipá-las com as ferramentas da reflexão dentro de um contexto de investigação-isto é de um contexto cuja metodologia é de autocrítica e autocorreção contínuas.

Para o educador realizar um bom trabalho ele necessita de competência, Rios (2011, p.56) define assim a competência: "Falar em competência significa falar em saber fazer bem" 
baseados então nessa premissa, quando o profissional da educação faz seu trabalho de forma competente, ele facilita o processo ensino-aprendizagem, sendo esse trabalho pautado na ética, promoverá um ambiente saudável em sua relação com o educando proporcionado um bem-estar em ambas as partes.

No entanto é conveniente que o professor não use do seu poder, autoridade e de sua competência para disseminar seus próprios valores e princípios, vinculados a seus conceitos sobre ética e moral, colocando-os como verdadeiros. Pelo contrário é necessário que esses não reduzam os conhecimentos a si próprios, sejam pessoais e/ou intelectuais, mas façam com que esses se alarguem e desta forma produzam-se novos conhecimentos com seus alunos, a partir das reflexões dentro da sala de aula.

\section{O espaço do educando na reflexão ética.}

Em torno dessa temática, qual o espaço ocupado pelo educando? Fala-se muito da responsabilidade do educador-que é de grande relevância, mas será o aluno apenas um expectador e/ou receptor? Engana-se quem pensa que o aluno é um mero expectador ou receptor das reflexões sobre a ética, ele é antes de tudo construtor juntamente com o educador, no entanto esse equívoco ocorre por estarem imersos dentro de uma perspectiva de seres em formação, e acabam por vezes recebendo esses títulos, que de forma alguma compete a eles, pelo contrário, cabe ressaltar que é nesse processo de formação que se faz presente a contribuição dos discentes nas reflexões éticas, como sujeitos de direitos e deveres, eles intervêm nesse processo instituindo regras e valores e as disseminando na sociedade.

Nessa perspectiva é apropriado que a ética seja trabalhada em sala de aula seguindo tanto os valores dos professores, quanto dos alunos, a melhor forma de alcançar os objetivos de educadores e educandos é manter o equilíbrio, sem que um domine ao outro, respeitando assim os princípios básicos da ética que para Rios (2011.) "São o respeito, a justiça e a solidariedade". À educação necessita deles para o bom desenvolvimento e a humanização dos homens. O respeito para que indivíduos estejam em harmonia, à justiça para que haja o equilíbrio e a solidariedade para a compreensão do homem.

Nesse sentido o professor tem com o aluno um compromisso social e ético, no seu processo de formação que segundo LIBÂNEO (2008, p.47) se concentra em:

Sua responsabilidade é preparar os alunos para se tornarem cidadãos ativos e participantes na família, no trabalho, nas associações de classe, na vida RPIRevista de Pesquisa Interdisciplinar, Cajazeiras, v. 1, Ed. Especial, 92 - 98, set/dez. de 2016. 
cultural e política. È uma atividade fundamentalmente social, porque contribui para a formação cultural e científica do povo, tarefa indispensável para outras conquistas democráticas.

Partindo dessa premissa é inegável a vivência efetiva de educadores e educandos na ética, da e na educação no tempo presente, sendo que professores e alunos se complementam, não sendo um mais importante do que outro, já que ambos têm papel primordial, cultural e social dentro da ética.

\section{Considerações Finais}

Na perspectiva discutida neste trabalho fica claro a relevância da ética na relação professor-aluno, tendo em vista que não há educação sem ética, pois é essa relação que permeia a formação integral dos educandos. A ética é a educação estão interligadas nessa jornada (relação professor-aluno) que deve ser vivenciada com base nos valores vitais para a vida social.

Nesse sentido, cabe ressaltar os benefícios do trabalho docente pautado por princípios éticos, que são relevantes para a formação do aluno/cidadão, proporcionando uma formação adequada, colaborando para a sua postura, no meio em que vive. No entanto, é necessário nos reconhecermos como seres inacabados, pois tanto os educadores quanto os educandos estão em processo de formação contínua e o melhor para ambas as partes é o respeito e a competência, juntamente com os princípios éticos. Seguindo este caminho podemos trabalhar de forma reflexiva e construir um novo rumo para a educação de uma sociedade realmente ética

Em suma, a partir desse artigo podemos perceber a abrangência e a complexidade da ética nas relações sociais. Também foi possível esclarecer algumas indagações e equívocos, tais como: o modismo do discurso ético, as interferências sociais e fatores que contribuem para uma relação harmoniosa entre educadores e educando, pautados na ética e competência. Ainda se colocou em foco a importância do educando para a construção de valores, referentes a essa temática, afinal no mundo contemporâneo a relação professor aluno torna-se norteadora da formação ética do individuo.

\section{REFERÊNCIAS:}

RPIRevista de Pesquisa Interdisciplinar, Cajazeiras, v. 1, Ed. Especial, 92 - 98, set/dez. de 2016. 
CORTELLA, Mario Sérgio. Qual a tua obra?: inquietações propositivas sobre gestão, liderança e ética. 19. Ed.- Petrópolis, RJ: Vozes, 2012.

LIBÂNEO, José Carlos. Didática. São Paulo: Cortez, 1994.

LIPMAN, Matthew. A Filosofia vai à escola. São Paulo: Summus, 1990.

RIOS, Terezinha Azeredo. Ética e Competência. - 20. Ed. - São Paulo: Cortez, 2011.

FREIRE, Paulo. Pedagogia da Autonomia: Saberes necessários à pratica educativa. São Paulo, Paz e Terra 2011. 